\title{
Tax, financial and credit stimulation of the technology, industrial and scientific parks activity as a factor of the innovative development in Ukraine
}

\author{
Viktor Oliinyk ${ }^{1, *}$, Viktor Mohylnyi ${ }^{2}$, Nataliia Vernydub $^{3}$, and Valerii Yatsenko $^{1}$ \\ ${ }^{1}$ Sumy State University, Department of Economic Cybernetics, 57, Petropavlivska str., Sumy, 40030, Ukraine \\ ${ }^{2}$ Sumy State University, Department of Finance and Entrepreneurship, 2, Rymskogo-Korsakova str., Sumy, 40007, Ukraine \\ ${ }^{3}$ Sumy State University, Education Management Department for Affiliated Institutions, 2, Rymskogo-Korsakova str., 40007 Sumy, \\ Ukraine
}

\begin{abstract}
The article analyzes the statistic indicators of the modern innovative development in Ukraine, based on which, the conclusions regarding the necessity to investigate measures for stimulation of either research and projects, or their further commercialization, are made. One of the most effective tools in the state policy in this sphere may be the tax stimulation of the innovative and investment activity. According to the results of the research, it is concluded that today tax system of Ukraine mostly performs the fiscal function and demonstrates low regulation efficiency. Besides, technology, industrial and scientific parks, which are catalysts of the innovative development in the whole world, do not operate in Ukraine, including the fact due to which there is a lack of privileges and preferences from the state. It was proposed to introduce a system of benefits for the payment of corporate income tax. Authors conclude that there is a necessity to reform the taxation system of enterprises in general, and in the part to stimulate the activity of participants from technology, industrial and scientific parks, on which the tax instruments can be tested taking into account the best world practices to control the innovative and investment activity.
\end{abstract}

\section{Introduction}

The innovative development of the entrepreneurship in different countries has its own national peculiarities and depends on the balancing of the business-environment efficiency, regulatory environment and state policy in the innovative development stimulation sphere. Three main factors: business-environment for innovations introduction, effective regulatory (normative) environment, implementation of the state policy to stimulate the innovative development, are necessary for successful development of the innovative system.

Based on the realities of the Ukrainian business, it is necessary to use various instruments to stimulate innovations in the entrepreneurship. Such instruments can be industrial, technology and scientific parks. Another problem for innovative development in Ukraine is a weak capital market development and investors' low willingness to risky investment.

The effective regulatory (normative) environment includes a patent system to protect intellectual property rights, administrative requirements to registration and economic entities' activity, the competition in the state purchases and placing of state orders, effective national taxation system.

The innovative development can be stimulated via state support of investigations in some branches, through the provision of state grants to develop the entrepreneurship, particularly, the innovative entrepreneurship, optimization of the high technological industries launch processes, the academic network development etc.

\section{Literature Review}

Such scientists as I. Alyeksyeyev, R. Zheliznyak [1] (financial and credit regulation of innovation activity of enterprises), H. Avihdor [2] (legislative regulation of innovation activity), V. Heiets [3] (general research on innovative development in Ukraine), A. Krysovatyy [4] (transformation of the tax system and improvement of tax policy), T. Medynska, R. Cherevata [5] (tax policy of stimulation of innovation and investment activity), L. Tarangul [6] (the effectiveness of fiscal and tax policy of Ukraine) studied the problems of the innovative and investment development stimulation, including its tax and financial and credit stimulation.

The roles of the technology, industrial and scientific parks in the country's innovative development and perspectives of their creation and functioning are studied in works of such native and foreign scientists as I. Dumanska [7] (principles of financing of the activity of industrial parks), J. Goraczovska [8] (technology parks influence on the innovation activity of enterprises), V. Halasiuk [9] (perspectives of creation of industrial parks in Ukraine), Yu. Kozak, I. Ukhanova [10, 11] (the role of technology parks in real economy and their development in the system of providing of innovation policy), A. Mazur, S. Pustovoit [12] (development of technology parks in Ukraine), etc.

* Corresponding author: oliynyk.viktor@gmail.com 
T. Bogolib [13] (capitalization and commercialization of university science activity), M. Butko, O. Popelo [14] (commercialization of research and innovation potential of entrepreneurship development), B. Clark [15] (development of entrepreneurial activity of universities), H. Etzkowitz [16] (technology transfer and entrepreneurship in universities), O. Kosenko [17] (assessment and development of intellectual and innovation activity), I. Mazur [18] (competitive business development based on the commercialization of research), J. Schumpeter [19] (general theory of economic development) dealt with the issue to activate studies and projects, the diversification of their financing sources and their results commercialization.

Although there are significant achievements of foreign and native scientists in these spheres, the level of their implementation is low in Ukraine. Given this, it is necessary to investigate deeper the historical peculiarities of the Ukrainian development and the best foreign practices to stimulate the entrepreneurship innovative development, which can be implemented in the formation of the state stimulation effective system in this sphere.

\section{Methods}

Methodological base of the paper covers methods of scientific research: historical and logical method, method of system analysis, statistical analysis, methods of induction and deduction, methods of analysis and synthesis.

\section{Discussions and Results}

We can indirectly use the Ease of Doing Business Index of the World Bank to assess the general regulatory environment of Ukraine, [20], according to which Ukraine shows consistently low rates, although a positive factor is the growth trend in the rating (in 2019 - 71 position, in $2018-76$, in $2017-80$, in $2016-83$, in $2015-96$, earlier - category $100+$ ). With a general improvement we can note decline in the areas of permitting and business taxation in Ukraine.

In the Table 1 we can see that there is a significant lag of Ukraine from neighboring countries in the Ease of Doing Business. At the same time, among the strengths of Ukraine are the following [20]:

- registration of enterprises and registration of property rights are relatively simple, fast and low cost;

- there is a tendency to improvement of international trade conditions at the same time compare with the countries of OECD it is easier to export and more difficult-to import;

- there is a tendency to improvement of protection of minority investors' interests;

- increasing of enforcement of contracts (compare with OECD countries there are shorter dispute resolution time, but high costs for them in Ukraine.

Also, according to Tables 1 and 2 , it can be concluded that it is advisable to study the experience of
Baltic region countries when reforming economic systems, which had the starting conditions for the development of a market economy similar to Ukraine in the 90 s of the twentieth century.

Table 1. Comparison of business conditions of Ukraine and some other countries of the region in 2019 (compiled by authors according to [20]).

\begin{tabular}{|l|c|c|}
\hline \multicolumn{1}{|c|}{ Economy } & DB 2019 Score & DB 2019 Rank \\
\hline Lithuania & 80.83 & 14 \\
\hline Estonia & 80.50 & 16 \\
\hline Latvia & 79.59 & 19 \\
\hline Poland & 76.95 & 33 \\
\hline Czech Republic & 76.10 & 35 \\
\hline Slovak Republic & 75.17 & 42 \\
\hline Romania & 72.30 & 52 \\
\hline Hungary & 72.28 & 53 \\
\hline Bulgaria & 71.24 & 59 \\
\hline Ukraine & $\mathbf{6 8 . 2 5}$ & $\mathbf{7 1}$ \\
\hline
\end{tabular}

It should also be noted some progress of Ukraine on the Global Competitiveness Index according to the World Economic Forum Study [21].

When analyzing the information in the Table 2 , it can be concluded that, on the one hand, there are positive changes - improvement in all indicators except companies' competitiveness, on the other hand, the integral index of competitiveness is rather low.

Table 2. Comparison of competitiveness in Ukraine and other countries of the region (compiled by authors according to [21]).

\begin{tabular}{|l|c|c|c|c|}
\hline \multirow{2}{*}{ Economy } & \multirow{2}{*}{$\begin{array}{c}\text { The Global } \\
\text { Competitiveness }\end{array}$} & \multirow{2}{*}{$\begin{array}{c}\text { GCI 2018 } \\
\text { Index 4.0 Score }\end{array}$} & \multicolumn{2}{|c|}{$\begin{array}{c}\text { Diff. from } \\
\text { Rank }\end{array}$} \\
\cline { 4 - 5 } & 71.2 & 29 & Score & Rank \\
\hline Czech Republic & 70.8 & 32 & - & -2 \\
\hline Estonia & 68.2 & 37 & +0.2 & - \\
\hline Poland & 67.1 & 40 & +0.7 & -2 \\
\hline Lithuania & 66.8 & 41 & +0.6 & -2 \\
\hline Slovak Republic & 66.2 & 42 & +1.4 & - \\
\hline Latvia & 64.3 & 48 & +0.9 & - \\
\hline Hungary & 63.6 & 51 & +1.2 & - \\
\hline Bulgaria & 63.5 & 52 & +1.3 & - \\
\hline Romania & $\mathbf{5 7 . 0}$ & $\mathbf{8 3}$ & $+\mathbf{3 . 1}$ & $+\mathbf{6}$ \\
\hline Ukraine & & & &
\end{tabular}

We can draw conclusions on a condition of innovative development of domestic business and the effectiveness of its regulation based on the analysis of official statistics of the State Statistics Committee of Ukraine [22].

As we can see in Figure 1, there is a relatively stable percentage of innovatively active enterprises, however, a significant part of innovations is accounted for nontechnological (organizational and / or marketing) innovations, it is confirmed by a tendency to reduce the share of innovative products in its total volume.

The data in Table 3 indicate steady decline in both the number of organizations performing research and development and the number of scientists, which is decreasing at a faster rate. In 2017, the share of research works performers (including satellite staff staff) in the total number of employed was $0.58 \%$, including 
researchers $-0.37 \%$. At the same time, in 2015, these indicators average for the EU-28 countries were 2.04\% and, accordingly, $1.33 \%$.

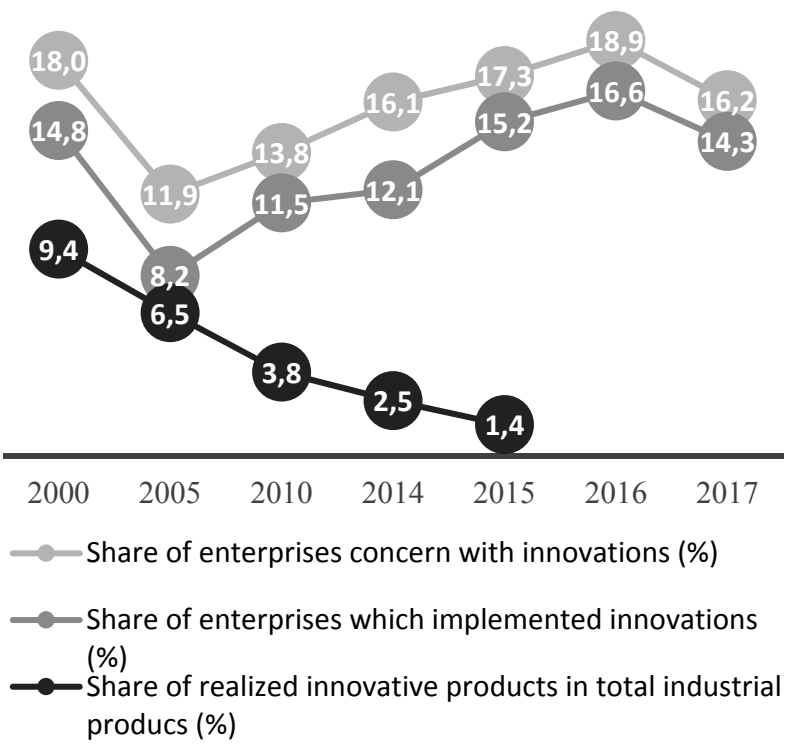

Fig. 1. Dynamics of innovative activity of enterprises of Ukraine (compiled by the authors according to [22]).

Table 3. Dynamics of scientific and research activity of enterprises in Ukraine (compiled by authors according to [22]).

\begin{tabular}{|c|c|c|c|}
\hline Year & $\begin{array}{c}\text { Number of } \\
\text { organizations which } \\
\text { carry out research } \\
\text { and development } \\
\text { (units) }\end{array}$ & $\begin{array}{c}\text { Number of } \\
\text { scientists, } \\
\text { excluding } \\
\text { satellite staff } \\
\text { (persons) }\end{array}$ & $\begin{array}{c}\text { Share of } \\
\text { scientific, } \\
\text { scientific and } \\
\text { technical } \\
\text { works in GDP } \\
\text { (\%) }\end{array}$ \\
\hline 2000 & 1490 & 120773 & 1.16 \\
\hline 2001 & 1479 & 113341 & 1.11 \\
\hline 2002 & 1477 & 107447 & 1.11 \\
\hline 2003 & 1487 & 104841 & 1.24 \\
\hline 2004 & 1505 & 106603 & 1.19 \\
\hline 2005 & 1510 & 105512 & 1.09 \\
\hline 2006 & 1452 & 100245 & 0.98 \\
\hline 2007 & 1404 & 96820 & 0.93 \\
\hline 2008 & 1378 & 94138 & 0.90 \\
\hline 2009 & 1340 & 92403 & 0.95 \\
\hline 2010 & 1303 & 89564 & 0.90 \\
\hline 2011 & 1255 & 84969 & 0.79 \\
\hline 2012 & 1208 & 82032 & 0.80 \\
\hline 2013 & 1143 & 77853 & 0.80 \\
\hline $2014^{1)}$ & 999 & 69404 & 0.69 \\
\hline $\left.2015^{1,2}\right)$ & 978 & 63864 & 0.55 \\
\hline $2016^{1,2)}$ & $\ldots 3)$ & 63694 & 0.48 \\
\hline $2017^{1,2)}$ & 963 & 59392 & 0.45 \\
\hline $1-$ & hereinafter statistical & data of $2014-2018$ & is provided \\
\hline
\end{tabular}
excluding temporarily occupied territories of Ukraine and the anti-terrorist operation zone;

2 - the methodology of statistical research has been changed, and therefore the direct comparison of data for 20002014 and 2015-2017 is incorrect;

3 - during the paper preparation generalized statistical data were absent.

The largest share was in Finland (3.21\% and 2.35\%), and the lowest was in Poland $(1.0 \%$ and $0.75 \%)$ and
Bulgaria $(1.0 \%$ and $0.65 \%)[22,23]$. Thus, we can conclude that there is the downward trend in research activity in Ukraine, and its significant lag in relation to the countries of the European Union.

The dynamics of research funding is also of concern (analyzing over the past 10 years we note that the corresponding share in GDP of Ukraine decreased more than twice). In 2017, the share of expenditure on research was $0.45 \%$ of GDP of Ukraine; on average in EU-28 countries $-2.07 \%$. The largest share was in Sweden $-3.40 \%$, and the smallest - in Macedonia, Latvia, Romania, Cyprus and Malta (from $0.36 \%$ to $0.54 \%)[22,23]$. Taking into account the gap in the amount of GDP per capita between Ukraine and the EU countries, the accumulated problems of the national economy look extremely serious.

An analysis of the data in the Table 4 indicates a significant gap between Ukraine and the EU countries both in terms of the amount of research and development funding and state support for this activity. At the same time, we note that EU countries demonstrate a steady growth in these indicators, while there is a downward trend in Ukraine. We also note that science can act as an accelerator of economic development only under the condition of the indicator of science-intensive GDP exceeds the mark of $0.9 \%$.

Table 4. Comparison of research and development funding in Ukraine and other countries in the region in 2017 (compiled by authors according to $[22,23])$.

\begin{tabular}{|l|c|c|}
\hline \multicolumn{1}{|c|}{ Economy } & $\begin{array}{c}\text { Gross } \\
\text { domestic } \\
\text { expenditure } \\
\text { on R\&D } \\
\text { (\% of GDP) }\end{array}$ & $\begin{array}{c}\text { Government budget } \\
\text { appropriations or outlays } \\
\text { on R\&D (\% of total } \\
\text { general government } \\
\text { expenditure) }\end{array}$ \\
\hline EU (28 countries) & 2.07 & 1.40 \\
\hline $\begin{array}{l}\text { Euro area } \\
\text { (19 countries) }\end{array}$ & 2.17 & 1.44 \\
\hline Czech Republic & 1.79 & 1.56 \\
\hline Hungary & 1.35 & 0.76 \\
\hline Estonia & 1.29 & 1.54 \\
\hline Poland & 1.03 & 0.88 \\
\hline Lithuania & 0.89 & 0.95 \\
\hline Slovak Republic & 0.88 & 0.90 \\
\hline Bulgaria & 0.75 & 0.60 \\
\hline Latvia & 0.51 & 0.59 \\
\hline Romania & 0.50 & 0.56 \\
\hline Ukraine & $\mathbf{0 . 4 5}$ & $\mathbf{0 . 4 6}$ \\
\hline
\end{tabular}

In $2017,21.9 \%$ of expenses in Ukraine were directed to the implementation of basic research, $23.6 \%$ - applied research and 54.5\% - scientific and technical (experimental) development. In general, the structure of research funding sources was following: $36.6 \%$ budgetary means, $27.9 \%$ - means from domestic customers, $24.4 \%$ - means from foreign and international sources of financing, $10.0 \%$ - own means, $1.1 \%$ - other means [22].

For the period 2014-2018, among the Top-50 organizations that have received the largest number of patents for inventions and utility model patents, there are 47 institutions of higher and postgraduate education, 2 scientific institutions and only 1 industrial enterprise 
[24]. In other words, the main generator of potentially commercially attractive developments in Ukraine is academic sector. Thus, out of 963 organizations (Table 3), which carried out research and development, $45.8 \%$ were public institutions, $62.7 \%$ were enterprises and $15.2 \%$ were institutions of higher education [22]. On the one hand, this demonstrates that activity of scientific institutions is more directed to basic researches, on the other hand, it is possible to draw a conclusion on low effectiveness of researches in Ukrainian business sector.

In addition, the activity of Ukrainian producers and generators on the protection of intellectual property rights both at the international and national levels is unsatisfactory (Fig. 2).

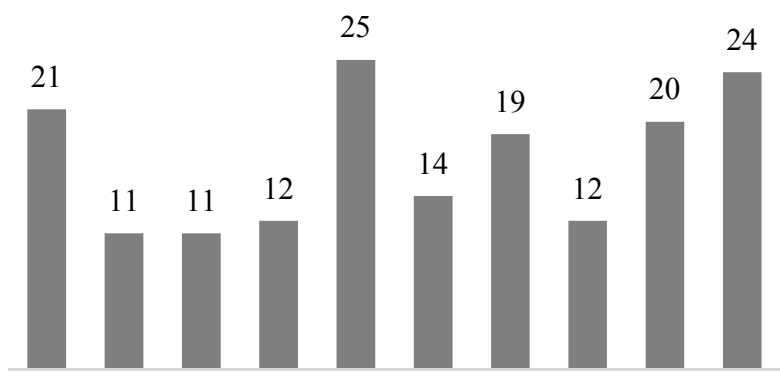

2009201020112012201320142015201620172018

Fig. 2. Number of patent applications filed at the European Patent Office from Ukraine from 2009 to 2018 [25].

Information that is presented in Figure 3 allows conclusions to be drawn about low patent activity in Ukraine - 1.2 applications for 1 million people, the average for EU-28 countries in 2017 was 106.8 applications according to the European Patent Office [23]), and that most applications are trademarks of goods and services.

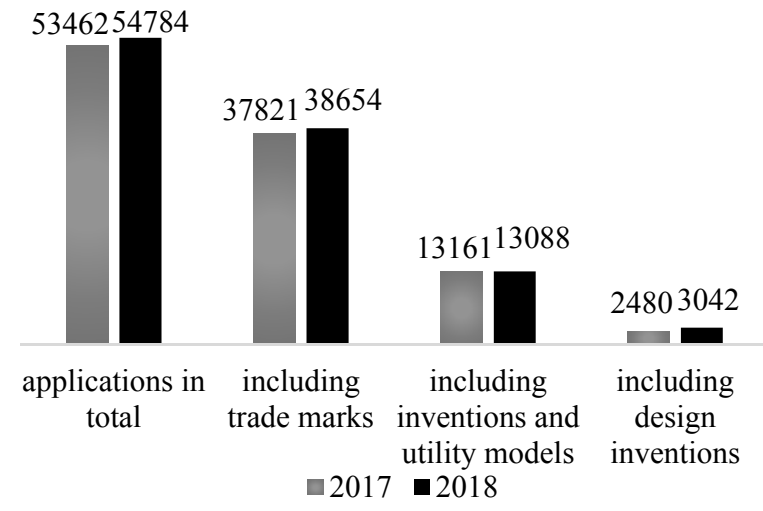

Fig. 3. Dynamics of patent applications for industrial property protection filed in Ukraine (compiled by authors according to [24]).

Thus, the necessity to stimulate research and development directly in enterprises, and to improve the processes of commercialization of research results of educational institutions and scientific institutions arises. Also, the intensification of activities to protect intellectual property rights at both the national and international levels requires special attention.

When analyzing legal and regulatory framework of Ukraine on supporting and stimulating innovations (Law of Ukraine "About the special regime of innovation activity of industrial parks", Law of Ukraine "On Innovation Activity", Tax Code of Ukraine, etc.), it is possible to draw a conclusion that significant benefits (including tax) in Ukraine are provided to public educational institutions and scientific institutions. At the same time benefits for research and development of the private sector are not provided. Also, most of the tools for stimulating innovation activities of business entities, technology, scientific and industrial parks are primarily declarative. Let's notice that a significant part of the benefits (including tax) for this type of activity was either canceled or their action was blocked by the Tax Code of Ukraine [26].

For the purpose of activization of the innovative development of Ukraine, it is necessary to provide a system of targeted incentives and preferences for both business entities that create and implement innovative products, and for expansion of investment opportunities in this area. Technology, industrial and scientific parks can be network which will allow to commercialize the existing research and development results more effectively, to intensify carrying out new researches (including directly at the enterprises) and also to be an accelerator of technological innovative development of business.

When analyzing the information about the activity of industrial parks in Ukraine [27] it is possible to draw conclusions that in February 2019 among 38 registered parks, 20 parks have no management company, 13 parks have no participants, the rest parks have from 1 to 4 participants. Also note that among the existing 16 technology parks in Ukraine, only 8 actually worked, and only 3 of them created almost all innovative products (and for the period since 2005, the activities of all technology parks gradually faded away). Comparing these facts with dynamics of innovative products selling (Table 3) it is possible to draw a conclusion that existing model of technology and industrial parks functioning as an instrument of stimulation of the economy innovative development is ineffective.

Taking into account concentration of researches mainly in the academic sector of Ukraine, creation of science and technology parks of "the second generation" on the American model for the solution of the tasks stated above shows potential. Such parks can be created on the basis of science parks that are under the management of the Ministry of Education and Science of Ukraine (there are 26 science parks for today). In addition, new technology parks can be created using a new model at leading research-type universities.

According to UNIDO research, the main problems of technology parks of the former USSR countries are access to funding and research deficit. We also note that the European Economic and Social Committee points out the low availability of financial resources as an obstacle to the development of technology and industrial parks in the EU countries. 
Analyzing conditions of innovation development of entrepreneurship in Ukraine, it is also necessary to note existence of not only the lack of financial resources for its implementation (not only for technology parks, but also for the economic system as a whole) and the low efficiency of the regulatory environment, but also the general unpreparedness of the business environment for the introduction of the innovation component in the management model. In particular, cautious attitude has arisen to risks of introducing fundamentally new products and high technologies. Also, neither companies nor the capital market are often willing to engage in high-risk activities. In addition, the management team of business entities is often not ready for the introduction of technological innovations (or does not have sufficient qualifications). Also, the low level of informatization of economic processes at the industrial enterprises often hinders the implementation of innovations [28].

Considering the fact that academic institutions in Ukraine are the main generators of research (they are leaders in the number of patents), we can recognize two main models for creation of effective interaction between the academic and manufacturing sectors in the field of commercialization of research results: stimulation requests from business entities to create new products and technologies in educational institutions and scientific institutions; promotion of the implementation of ready-made research results into production. In modern realities, the first model is rather difficult to implement, given the low innovativeness of the business environment of Ukraine and the current condition of the impact of research on the implementation of innovative products. Thus, development of the second model may be a priority. The implementation of this model, among other things, is possible through the creation of technology parks of the "second generation" in close cooperation with leading universities in Ukraine (technology, industrial parks of the "first generation" functioned unsystematically, inconsistently and unsynchronized). In addition, the updated technology parks can solve other problems of entrepreneurship development, in particular in the formation of an effective business environment for innovations.

For putting into practice these tasks it is necessary to implement the following complex of measures:

1. Systematization, organization of the legal and regulatory framework of Ukraine on support and stimulation of innovation and investment activity of business entities. When updating the legal and regulatory framework should be foreseen:

1.1. New procedure of creation and state support of technology, scientific and industrial parks activities in Ukraine.

1.2. Clear mechanisms of financial, credit and tax instruments when stimulate research (both directly at enterprises and with placing orders for research and development in academic institutions), innovation and investment activities of business entities.

1.3. Consolidation of property rights on intellectual property objects for their producers and generators (except for developments relating to national safety and which were funded by the respective customers) and strengthening the protection of these rights at the national and international levels.

2. Elaboration of the National Strategy for the business environment development, which in particular will include targeted programs for monitoring, state support and stimulating, on a competitive basis, for startup centers, business incubators, business accelerators, venture investors, research and development funds, advanced training systems and professional development for stuff of business entities. At the same time, it is necessary to determine both the sources of funding for such activities and the direction of the targeted use of appropriate financial resources.

3. Creation of a unified register of commercially attractive developments and technologies with mandatory expertise of all developments financed from public sources (as well as all new technologies that will be created through basic financing of higher education institutions, which is planned to be introduced in Ukraine) and voluntary expertise of other developments [11]. At the same time it is necessary to attract professional (branch) associations of enterprises for expertise.

4. Creation of state (or participation in the financing of non-state) funds for financing joint research of collaborations of academic and industrial organizations on a grant basis (according to the model for financing grants from the European Union).

The importance of state support for innovative development of the economy as a whole, and in particular technology parks, is confirmed by the dynamics of development and decline of technology parks of the "first generation" in Ukraine, which took place in conditions of substantial legal instability and declarativeness of many legal provisions. The collapse of technology parks began at the same time with the abolition of their state support and targeted tax subsidies.

In our opinion, the use of special tax regimes has a high potential as a self-regulating tool for stimulating innovative investment activity. The advantage of tax incentives for research and development is that they are provided not to academic organizations, but to manufacturing enterprises and / or investors. This creates a competitive environment with high demand for innovations. Such an approach creates a self-regulating system of linking the interests and responsibilities of investors, business and academic institutions.

In the foreign practice of taxation, the general tendency today is an increase in the proportion of benefits ensuring the formation of a favorable innovation climate. It also reduces direct government funding for research and development while increasing the aggregate contribution rate of these expenditures in GDP.

The US experience shows that the amount of underreceived tax benefits is equivalent to corporate spending on innovation, which creates preconditions for revitalizing the economy and increasing tax revenues in the long term. When the amount of tax revenues exceeds the amount of tax benefits provided, tax incentives are also beneficial for the state [29].

Note that the tax burden on enterprises in Ukraine is relatively high $-41.7 \%$ (average for OECD countries - 
39.8\%, for Europe and Central Asia - 32.3\%) (Table 5).

Table 5. Comparison of the tax systems efficiency in Ukraine and other countries of the region in 2019 (concluded by authors according to [20]).

\begin{tabular}{|l|c|c|c|c|}
\hline Economy & $\begin{array}{c}\text { DB 2019 } \\
\text { Paying } \\
\text { Taxes } \\
\text { Score }\end{array}$ & $\begin{array}{c}\text { World } \\
\mathbf{2 0 1 9} \\
\text { rank }\end{array}$ & $\begin{array}{c}\text { Total tax and } \\
\text { contribution } \\
\text { rate (\% of } \\
\text { profit) }\end{array}$ & $\begin{array}{c}\text { The time it } \\
\text { takes to } \\
\text { prepare, file } \\
\text { and pay the } \\
\text { taxes }\end{array}$ \\
\hline Latvia & 89.74 & 13 & 36.0 & 168.5 \\
\hline Estonia & 89.56 & 14 & 48.7 & 50.0 \\
\hline Lithuania & 88.66 & 18 & 42.6 & 99.0 \\
\hline $\begin{array}{l}\text { Czech } \\
\text { Republic }\end{array}$ & 81.42 & 45 & 46.1 & 230.0 \\
\hline $\begin{array}{l}\text { Slovak } \\
\text { Republic }\end{array}$ & 80.62 & 48 & 49.7 & 192.0 \\
\hline Romania & 80.30 & 49 & 40.0 & 163.0 \\
\hline Ukraine & $\mathbf{7 9 . 3 5}$ & $\mathbf{5 4}$ & $\mathbf{4 1 . 7}$ & $\mathbf{3 2 7 . 5}$ \\
\hline Poland & 76.49 & 69 & 40.7 & 334.0 \\
\hline Hungary & 73.81 & 86 & 40.3 & 277.0 \\
\hline Bulgaria & 72.00 & 92 & 27.7 & 453.0 \\
\hline
\end{tabular}

You should also pay attention to the high cost of business time to prepare, file and pay the taxes: in Ukraine - 327.5 hours per year, average for OECD countries - 159.4, for Europe and Central Asia - 214.8.

The data in Table 6 show that the most promising is the corporate income tax in terms of stimulating the innovation activity of enterprises in Ukraine, on the one hand, its share in the total tax liabilities of enterprises is quite substantial, on the other hand this tax has a high potential to perform the regulatory function in the long run. In addition, in recent years, revenues from this tax account for about $9 \%$ of the tax revenues of the consolidated budget of Ukraine.

Table 6. The amount of taxes and mandatory contributions payable by the business in Ukraine, expressed as a share of commercial profits (compiled by authors according to [20]).

\begin{tabular}{|l|c|c|c|}
\hline $\begin{array}{c}\text { Tax or mandatory } \\
\text { contribution }\end{array}$ & $\begin{array}{c}\text { Statutory } \\
\text { tax rate }\end{array}$ & Tax base & $\begin{array}{c}\text { Total tax and } \\
\text { contribution rate } \\
\text { (\% of profit) }\end{array}$ \\
\hline $\begin{array}{l}\text { Unified Social } \\
\text { Contribution }\end{array}$ & $22 \%$ & $\begin{array}{c}\text { gross } \\
\text { salaries }\end{array}$ & 29.56 \\
\hline $\begin{array}{l}\text { Corporate income } \\
\text { tax }\end{array}$ & $18 \%$ & $\begin{array}{c}\text { taxable } \\
\text { profit }\end{array}$ & 11.00 \\
\hline Land tax & $\begin{array}{c}\text { various } \\
\text { rates }\end{array}$ & $\begin{array}{c}\text { land area } \\
\text { and value }\end{array}$ & 1.10 \\
\hline $\begin{array}{l}\text { Environmental } \\
\text { taxes }\end{array}$ & $\begin{array}{c}\text { various } \\
\text { rates }\end{array}$ & $\begin{array}{c}\text { ton of } \\
\text { waste }\end{array}$ & 0.01 \\
\hline Totals in 2019 & & & 41.7 \\
\hline
\end{tabular}

As the information in Table 7 shows, the taxation of profits in Ukraine and in the closest EU countries differs significantly both in tax rates and tax base and in tax calculation methods (including tax benefits for business entities), that leads to significant heterogeneity in shares this tax in the profits of enterprises.

The possibility of transition from the current scheme of taxation of profit to taxation of distributed profit has been actively discussed recently in Ukraine. Such system is used by Estonia (Table 7) and other countries of the
Baltic region plan to introduce it. In our opinion, such a reform of the taxation system may become a prerequisite for increasing the shadowing of the Ukrainian economy instead of stimulating the investment activity.

Table 7. Comparison of the corporate income tax or dividend tax in Ukraine and other countries of the region in 2019 (concluded by authors according to [20]).

\begin{tabular}{|l|c|c|c|}
\hline Economy & $\begin{array}{c}\text { Statutory tax } \\
\text { rate (\%) }\end{array}$ & Tax base & $\begin{array}{c}\text { Total tax and } \\
\text { contribution rate } \\
\text { (\% of profit) }\end{array}$ \\
\hline \multirow{2}{*}{ Hungary } & 9 & taxable profit & 3.22 \\
\cline { 2 - 4 } Bulgaria & 10 & $\begin{array}{c}\text { adjusted net } \\
\text { revenue }\end{array}$ & 0.88 \\
\hline $\begin{array}{l}\text { Czech } \\
\text { Republic }\end{array}$ & 19 & taxabome & 4,94 \\
\hline Lithuania & 15 & taxable profit & 5.21 \\
\hline Latvia & 15 & taxable profit & 6.92 \\
\hline Estonia & $20 / 80$ & $\begin{array}{c}\text { distributed } \\
\text { dividends }\end{array}$ & 7.91 \\
\hline $\begin{array}{l}\text { Slovak } \\
\text { Republic }\end{array}$ & 21 & taxable profit & 9.09 \\
\hline Romania & 16 & taxable profit & 12.27 \\
\hline Ukraine & $\mathbf{1 8}$ & $\begin{array}{c}\text { taxable } \\
\text { profit }\end{array}$ & $\mathbf{1 1 . 0 0}$ \\
\hline Poland & 19 & taxable profit & 14.48 \\
\hline
\end{tabular}

It is useful to analyze the best world practices on preferential taxation of profits of business entities that can be applied in Ukraine:

- application of tax holidays to start-up companies;

- reduction of tax liabilities of enterprises for the amount of expenses for development and research;

- deduction from the taxable profit the value of intellectual property rights which acquired for implementation in production or scientific activities;

- deduction from the taxable profit the expenses of companies for advanced training, retraining and professional development, improving financial literacy [30] of staff (within certain limits, which can be calculated either as a part of the profits or depending on the number of employees of the enterprise with reference to the minimum wage);

- exemption (within a certain period) from taxation of investment profits derived from equity participation in the authorized capital of start-up and spin-off companies; - applying a reduced income tax rate for funds engaged exclusively in long-term and medium-term venture capital investments (or granting the status of non-profit organizations to the funds, which are financed by means of state or local budgets);

- return to the practice of accelerated depreciation of fixed assets which involved in the creation of innovative products;

- the possibility of including in gross expenses representative and marketing costs for the promotion of innovative products is considered appropriate.

Application of preferential tax regimes for the profits of enterprises in the short term can give noticeable stimulating effects for enhancing the investment and innovation activities of enterprises without a significant 
reduction in tax revenues of the consolidated budget of Ukraine (due to the relatively small fiscal value of this tax). At the same time, the implementation of the tax benefits proposed above can lead to significant longterm macroeconomic benefits. In addition, taking into account the European integration processes in Ukraine, it is necessary to take into consideration the factors of tax competition, which greatly affect the international mobility of capital.

In order to stimulate the development of technology parks in Ukraine, as an additional privilege, exemption from paying a land tax may also be appropriate.

Also, the exemption of innovative products from VAT may be applied, although this may lead to the possibility of avoiding payment of this tax. However, the release of technology parks from VAT payment when importing equipment, materials and components that are not manufactured in Ukraine and are intended for the implementation of innovative projects seems rather progressive.

In order to stimulate an increase in the number of staff involved in research and development, it may also be expedient to introduce lower tax rates on the incomes of hired workers of the relevant category and corresponding charges on such wages.

\section{Conclusions}

The analysis of the Ukrainian development dynamics demonstrates the stable decrease of both research and innovative activity. It is reflected, particularly, in positions of Ukraine to range the economic systems competitiveness. Despite the systemic reforms, which are carried out in the country, and national positions improvement in the above ratings, it is obvious that Ukraine lags behind European neighboring states.

Given that, it is possible to make conclusions regarding the necessity to increase the studies financing and to activate their results commercialization.

The carried out analysis of the studies and projects financing proves the essential scientific potential of Ukraine, which is not practically involved into the native enterprises development:

- the present budget financing system of the scientific activity is mainly oriented to support the academic institutions, but not to introduce their results in practice; - significant financing of the research, owing to the foreign sources, practically does not influence the share of the innovative production in Ukraine;

- the essential share of the research financing thanks to the native purchasers' funds does not cause the relevant activation of their innovative development.

In order to solve these problems, it is necessary to increase the state financing of the research, which will be distributed on a competitive basis. It is necessary to develop the integral strategy to stimulate orders for scientific and scientific technical production from the economic entities, and to carry out research directly at the enterprises.

Given the fact that the main part of studies in Ukraine is carried out at the academic institutions, technology parks may be the link, which is able to activate the innovative development of the entrepreneurship at the modern stage, but which is a "bridge" between the research academic institutions and real sector of economy.

The analysis shows that the current industrial, technology and scientific parks do not practically work. The problems of the national economy can be solved, including the problem to create technology parks of the "second generation", which is proposed in this article.

Today, it is necessary to systematize and modernize the legal and regulatory base of Ukraine to support the innovative and investment activity regarding the extension of the researching activity stimulation [31] and their results commercialization.

Under modern conditions, it is effective to provide preferences in the sphere of enterprises' profit taxation regarding the economic entities' activities, oriented to the innovative development of the entrepreneurship without changes in general principles to levy this tax. Privileges and tax subsidies of the above technology parks of the "second generation" can be tested at the first stage. Subsequently, the appropriate privileges may be extended to all economic entities.

Profit tax privileges may be used separately (defining the limits for each privilege) and / or complexly (defining the maximum total privilege for the enterprise or technology park).

Perspectives for further studies consist in the investigation of the economic principles for creation and functioning of the "second generation" technology parks and in the objectivation of the tax preferences incentives for the economic entities (including technology parks) from the view point to balance the short-term fiscal and long-term strategic tasks of the state.

\section{References}

1. Alyeksyeyev, I.V., Zheliznyak, R.Y.: Vazhlyvist pravylnoho pidboru podatkovykh pilh i shliakhiv yikh nadannia pry podatkovomu stymuliuvanni innovatsiinoi diialnosti pidpryiemstv (Importance of correct selection of tax privileges and ways of providing them with tax stimulation of innovation activity of enterprises). Bus. Inf. 2, 314-320 (2014)

2. Avihdor, H., et al.: Innovatsiina polityka: yevropeiskyi dosvid ta rekomendatsii dlia Ukrainy (Innovation policy: European experience and recommendations for Ukraine). Feniks, Kyiv (2011)

3. Heiets, V.M. (ed.): Innovatsiina Ukraina 2020: natsionalna dopovid (Innovative Ukraine 2020: National Report). Kyiv, NAN Ukrainy (2015)

4. Krysovatyy, I.A.: Mozhlyvosti zastosuvannia v Ukraini pozytyviv mizhnarodnoho dosvidu podatkovoho rehuliuvannia investytsiinoinnovatsiinoi diialnosti (Application of the Positive International Experience of Tax Regulation of Investment and Innovation Activity in Ukraine). Business Inform, 10, 347-350 (2013)

5. Medynska, T.V., Cherevata, R.Y.: Podatkove 
stymuliuvannia innovatsiinoi diialnosti v Ukraini ta Polshchi v umovakh yevropeiskoho vyboru (Tax stimulation of innovative activity is in Ukraine and Poland in the conditions of the European choice). Economy and Society. 13, 1149-1156 (2017)

6. Tarangul, L.L. (ed.): Biudzhetna pidtrymka ta podatkove stymuliuvannia natsionalnoi ekonomiky Ukrainy (Budget support and tax incentives in national economy of Ukraine). National university of state tax service of Ukraine, Irpin (2012)

7. Dumanska, I.Y.: Obhruntuvannia zasad stvorennia tekhnoparkiv $\mathrm{V}$ apk ta yikh finansuvannia (Submission of Development of Technoparks in AIC and Their Financing). Market Infrastructure. 19, 472-477 (2018)

8. Gorączkowska, J.: Influence of business support organizations on innovation activity in manufacturing companies in the Masovian Voivodeship in Poland. Equilibrium. Quarterly J. of Econ. and Economic Policy. 13(4), 741-759 (2018)

9. Halasiuk, V.: Industrialni parky: svitovyi dosvid ta perspektyvy stvorennia v Ukraini (Industrial Parks: World Experience and Perspectives of Creation in Ukraine). Ekonom. analiz. 28(1), 40-50 (2018)

10. Kozak, Yu., Ukhanova, I.: Sutnist ta rol tekhnoparkiv $\mathrm{v}$ innovatsiinomu rozvytku krainy (Content and role of technoparks in innovative development of country). Rynkova ekonomika: suchasna teoriia i prakt. upravl. 16(1), 40-54 (2017)

11. Ukhanova, I.: Rozvytok tekhnoparkovykh struktur $\mathrm{v}$ systemi zabezpechennia derzhavnoi innovatsiinoi polityky v Ukraini. Dissertation, Odessa National Polytechnic University (2014)

12. Mazur, A., Pustovoit S.: Social and Economic Efficiency of Academic Technoparks of Ukraine. Nauka ta innovatsii. 12(3), 63-73 (2016). doi:10.15407/scin12.03.063

13. Bogolib, T.M.: Komertsializatsiya naukovykh rozrobok universytetiv. Ekonomika Ukrayiny (Commercialization of scientific developments of universities). Ukraine econ. 626(1), 33-50 (2014)

14. Butko, M., Popelo, O.: Komertsializatsiia rezultativ naukovo-tekhnichnoi diialnosti $\mathrm{V}$ umovakh pohlyblennia intehratsiinykh protsesiv (Commercialization of the results of scientific and technological activities under integration processes deepening). Problemy i perspektyvy ekonomiky ta upravlinnia. 1(1), 7-20 (2015)

15. Clark, B.: Creating Entrepreneurial Universities: Organizational Pathways of Transformation. IAU Press: Elsevier Science, Pergamon (1998)

16. Etzkowitz, H.: The Triple Helix: UniversityIndustry-Government Innovation In Action. Routledge, London (2008)

17. Kosenko, O.P.: Komertsializatsiia intelektualnoinnovatsiinykh tekhnolohii (Commercialization of intellectual innovation technologies). National Technical University “KPI”, Kharkiv (2015)
18. Mazur, I.: Komertsializatsiia naukovykh rozrobok yak faktor konkurentnoho rozvytku pidpryiemnytstva (Commercialization of scientific developments as factor of competitive development of business). Visnyk Kyyivskoho nats. univ. imeni Tarasa Shevchenka. Ekonomika. 148, 5-8 (2013)

19. Schumpeter, J.A.: The Theory of Economic Development: An Inquiry Into Profits, Capital, Credit, Interest, and the Business Cycle. Transaction Publishers, New Brunswick and London (2011)

20. World Bank: The Doing Business project. Measuring Business Regulations. http://doingbusiness.org (2019). Accessed 29 Mar 2019

21. World Economic Forum: The Global Competitiveness Report 2018. http://reports.weforum.org/global-competitivenessreport-2018 (2019). Accessed 29 Mar 2019

22. State Statistics Service of Ukraine. http://www.ukrstat.gov.ua (2019). Accessed 29 Mar 2019

23. EC: Eurostat. https://ec.europa.eu/eurostat/ (2019). Accessed 29 Mar 2019

24. State enterprise "Ukrainian institute of intellectual property": Promyslova vlasnist u tsyfrakh. Pokaznyky diialnosti za 2018 rik (Industrial property in figures. Activity indicators for 2018). Ministries of economic development and trade of Ukraine, Kyiv. https://tinyurl.com/yycvjg6s (2019). Accessed 29 Mar 2019

25. Statista. https://statista.com. Accessed 29 Mar 2019

26. Podatkovyi kodeks Ukrainy (Tax Code of Ukraine). https://zakon.rada.gov.ua/laws/show/2755-17/ (2019). Accessed 29 Mar 2019

27. Ministry of Economic Development and Trade of Ukraine. http://www.me.gov.ua. Accessed 29 Mar 2019

28. Babenko, V.O., Petuhova, V.O., Perepelitsia A.S.: Forming of informatization strategic prospects for Ukraine in conditions of world economy globalization. Scientific Bulletin of Polissia. 2(10), vol. 1, 24-34 (2017). doi:10.25140/2410-95762017-1-2(10)-24-34

29. Nikiforov, A.Ye.: Podatkove stymuliuvannia innovatsiinoi diialnosti (Tax incentives of innovative activity). Finansy Ukrainy. 162(5), 78-86 (2009)

30. Bielova, I., Oliinyk, V., Nilova, N., Nilova, M.: Causal relationship of financial literacy with indicators of the financial and social sectors. Financial and credit activity: problems of theory and practice. 27(4), 457-467 (2018)

31. Leheza, Ye., Savielieva, M., Dzhafarova, O.: Structural and Legal Analysis of Scientific Activity Regulation in Developed Countries. Baltic Journal of Economic Studies. 4(3), 147-154 (2018) doi:10.30525/2256-0742/2018-4-3-147-157 